Article

\title{
Governing for Integrated Water and Flood Risk Management: Comparing Top-Down and Bottom-Up Approaches in Spain and California
}

\author{
Anna Serra-Llobet ${ }^{1, *}$, Esther Conrad ${ }^{2,3}$ and Kathleen Schaefer ${ }^{4}$ \\ 1 Institute of International Studies, University of California, Berkeley, 215 Moses Hall, Berkeley, \\ CA 94720, USA \\ 2 Gould Center for Conflict Resolution, Stanford Law School, Stanford, CA 94305, USA; esther@stanford.edu \\ 3 The Water in the West Program, Woods Institute for the Environment, Stanford University, Stanford, \\ CA 94305, USA \\ 4 Center for Catastrophic Risk Management, University of California, Berkeley, 8th Floor Barrows Hall, \\ Berkeley, CA 94720, USA; kathy.schaefer@comcast.net \\ * Correspondence: annaserrallobet@gmail.com; Tel.: +1-510-604-5331
}

Academic Editor: Matt Kondolf

Received: 17 June 2016; Accepted: 9 September 2016; Published: 12 October 2016

\begin{abstract}
Flood risk management in the context of Integrated Water Resource Management (IWRM) is becoming widely accepted as an approach to improving resilience in light of increasing flood risks due to climate change and other factors. This paper contributes to a better understanding of the governance arrangements needed for effectively implement integrated approaches to managing flood risk. We compare how IWRM and flood risk management have been operationalized within "top-down" and "bottom-up" governance arrangements in the European Union and the United States. We focus in particular on two case study regions, the Catalan coastal region in Spain and the San Francisco Bay Area in California, which have strong similarities in economy, climate, and environmental values, but different institutional settings. Our findings contribute empirical evidence of the need for a balance between "top-down" and "bottom-up" approaches. While the San Francisco Bay Area's strongly collaborative and participatory approach has generated new connections among flood managers and other stakeholders, the lack of a central entity with the capacity and mandate for on-going coordination and region-wide risk assessments appears to constrain its ability to support integrated and adaptive management. The European Union's top-down approach and the presence of a central authority at the river basin scale have led to a consolidated regional plan in Catalonia encompassing all phases of flood risk management, but the degree of engagement and opportunities for knowledge-sharing among participants may be more limited.
\end{abstract}

Keywords: Integrated Water Resource Management (IWRM); integrated flood risk management; water governance; California; Spain

\section{Introduction}

Integrated Water Resources Management (IWRM) has gained widespread currency as an approach for managing water sustainably in the face of increasing demands and uncertainties [1,2]. As defined by the Global Water Partnership, IWRM is "a process which promotes coordinated development and management of water, land, and related resources in order to maximize economic and social welfare in an equitable manner without compromising the sustainability of vital ecosystems" [3]. IWRM is closely intertwined with the notion that water resources should be managed at the river basin or catchment scale, in order to promote the holistic management of all ecological and social elements of a water system [2,4] (the concept of river basin planning was not always identified with 
environmental sustainability. In the 19th century, river basin scale planning was promoted as the best way to maximize human uses of water for hydropower, water supply, and flood control [4]. However, amidst growing recognition of the environmental impacts of dams and other water infrastructure in the 1980s, the meaning of the concept evolved to emphasize the need for "integrated" management at the river basin scale of all elements of a water system, toward equity and environmental sustainability, as well as economic development [2]). In addition, IWRM calls for coordination across all aspects of water management, including water supply, quality, flood risk, and ecosystem health. Integrated planning and management at the scale of a river basin or other ecological system can enable a more comprehensive assessment of risks and uncertainties, and promote learning and adaptation as new risks emerge [5]. Such integrated approaches are particularly important in Mediterranean climates, which are subject to high variability and extremes in rainfall [6]. Furthermore, as climate change leads to increased temperatures and changes in patterns of precipitation, management strategies that are resilient in the face of extremes are even more critical [7]. Adaptive water management-also referred to as "adaptive integrated water management" - is an extension of the IWRM concept, emphasizing multi-stakeholder coordination and iterative decision-making to enable learning [8-10]. IWRM has been widely embraced by the water management community worldwide. However, as many scholars and practitioners have noted, the concept has been interpreted in varying ways, and has often been challenging to put into practice $[1,11]$.

One reason for these difficulties is the lack of an adequate understanding of the governance arrangements needed for success [12]. While there is widespread acknowledgement that no single governance approach is effective in all contexts, researchers have sought to define broad principles for the design of integrated and adaptive water governance, which emphasize multi-level structures, collaborative decision-making, and broad stakeholder participation [13-15]. These findings are by no means conclusive, and many questions still remain [16]. In particular, there is debate over the scale at which such governance should be organized, and whether authority for different aspects of water management should be centralized, or distributed across multiple actors. The concept of IWRM has often been associated with the creation of new management entities at the scale of river basins or catchments, with centralized authority over water management [17]. This approach has certain advantages, particularly in facilitating coordination across interconnected hydrologic and ecological systems. However, other scholars have noted that river basin or catchment boundaries may not match other important ecological boundaries, and that new authorities may lack legitimacy if they do not follow jurisdictional boundaries, creating more coordination problems $[13,18]$. Some have advocated decentralized or "polycentric" structures, in which existing entities, which may not follow river basin or catchment boundaries, but hold authority over different aspects of water management collaborate with one another at appropriate scales for solving water management problems [10]. These arrangements are often viewed as more conducive to learning due to dialogue occurring across multiple parties, a critical feature for adaptive management [19]. Huntjens et al. [14,20] argue that a balance is need between "bottom-up" (i.e., collaborative and participatory) governance, and centralized "top-down" control, particularly in large river basins. They point out that central authorities can play important roles in promoting participation, resolving conflicts, and setting common standards [20]. They also find that governance in river basins that are generally considered "bottom-up", such as in the Lower Rhine in the Netherlands-actually have considerable "top-down" character [9]. Thus far there has been little other research on how "top-down" and "bottom-up" approaches work in practice in the context of IWRM, and what a balanced approach might look like.

This paper seeks to address the gap in research by comparing "top-down" and "bottom-up" approaches to IWRM in the European Union (EU) and the United States (US). By "top-down", we mean governance in which a central government agency holds authority to set goals and guide implementation; by "bottom-up" we refer to governance in which multiple governmental and non-governmental entities agree to collaboratively decide upon a common set of goals and implementation strategies (in some literature, "top-down" governance has been equated with 
decision-making by government agencies only, whereas "bottom-up" invokes governance that involves stakeholder participation (see Reference [16], p. 200). On the other hand, Huntjens et al. [20] (p. 276) refer to "top-down" as the centralization of authority, a role that can include encouraging participatory processes. Here, we use the terms primarily to distinguish between where the authority lies to set rules, acknowledging that a "top-down" arrangement may include opportunities for public input in the process, as in the case of the EU Water Framework Directive). We present a detailed analysis of two case study regions within the EU and the US - the Catalan coastal region, Spain, and the San Francisco Bay Area, California, which have similar climatic, hydrologic and socio-economic features but differ significantly with respect to their institutional settings for water management. We assess the implications of Catalonia's "top-down" governance leads versus San Francisco Bay Area's "bottom-up" approach. In so doing, we hope to help policy-makers and water managers identify which approaches to IWRM might be most effective in a given context.

We focus on how flood risk management has been operationalized within the context of IWRM in our two case studies. Managing flood risks in an integrated manner along with water supply, water quality and environmental goals is a critical element of IWRM [21]. This represents a transition away from a sole reliance on structural methods of flood control, and toward a flood risk management approach [16,22] that contextualizes risk as a process and not as a phenomenon isolated in time and space $[23,24]$, emphasizing all the temporal phases (pre, during and post event) involved in the occurrence of a hazard $[25,26]$. Figure 1 defines four phases that should be included in the design and implementation of an integrated flood risk management plan: (1) flood risk characterization (hazard and risk assessment and mapping taking into account climate change); (2) mitigation (prevention and protection measures); (3) emergency management (preparation and response measures); and finally; (4) short and long-term recovery. The characterization of flood risks utilizes probabilities to assess the likelihood of particular outcomes, and mitigation efforts seek to minimize, but not necessarily eliminate, risks, for which robust emergency management and recovery efforts are needed. This risk-based approach is particularly needed in light of climate change, which is increasing the risk of extreme flood events in many parts of the world [7]. The "Room for Rivers" policy in the Netherlands, which utilizes spatial planning allow more room for rivers to flood instead of continually raising dikes, provides a useful example. This effort has been motivated in part by a recognition that under climate change, communities need greater capacity to cope with flood risks as they increase over time [27]. Achieving flood risk management presents considerable governance challenges, because it requires coordination across a wide range of public and private actors, not only in water management but also in land use [11]. The shift toward flood risk management provides an opportunity to examine the particular challenges involved in governance of IWRM efforts, and the implications of "top-down" versus "bottom-up" approaches.

This paper is organized as follows. First we summarize our methods and introduce our two case studies: The Catalan coastal region in Spain and the San Francisco Bay Area in California. We then provide an overview of the larger institutional context for IWRM and flood risk management in the Spain and the US. We then analyze in detail how flood risk management has been operationalized in the context of IWRM in our two case studies, with a specific focus on the implications of the "top-down" and "bottom-up" approaches that they employ. We conclude by discussing our findings and contributions to literature on the governance of adaptive and integrated water management. 


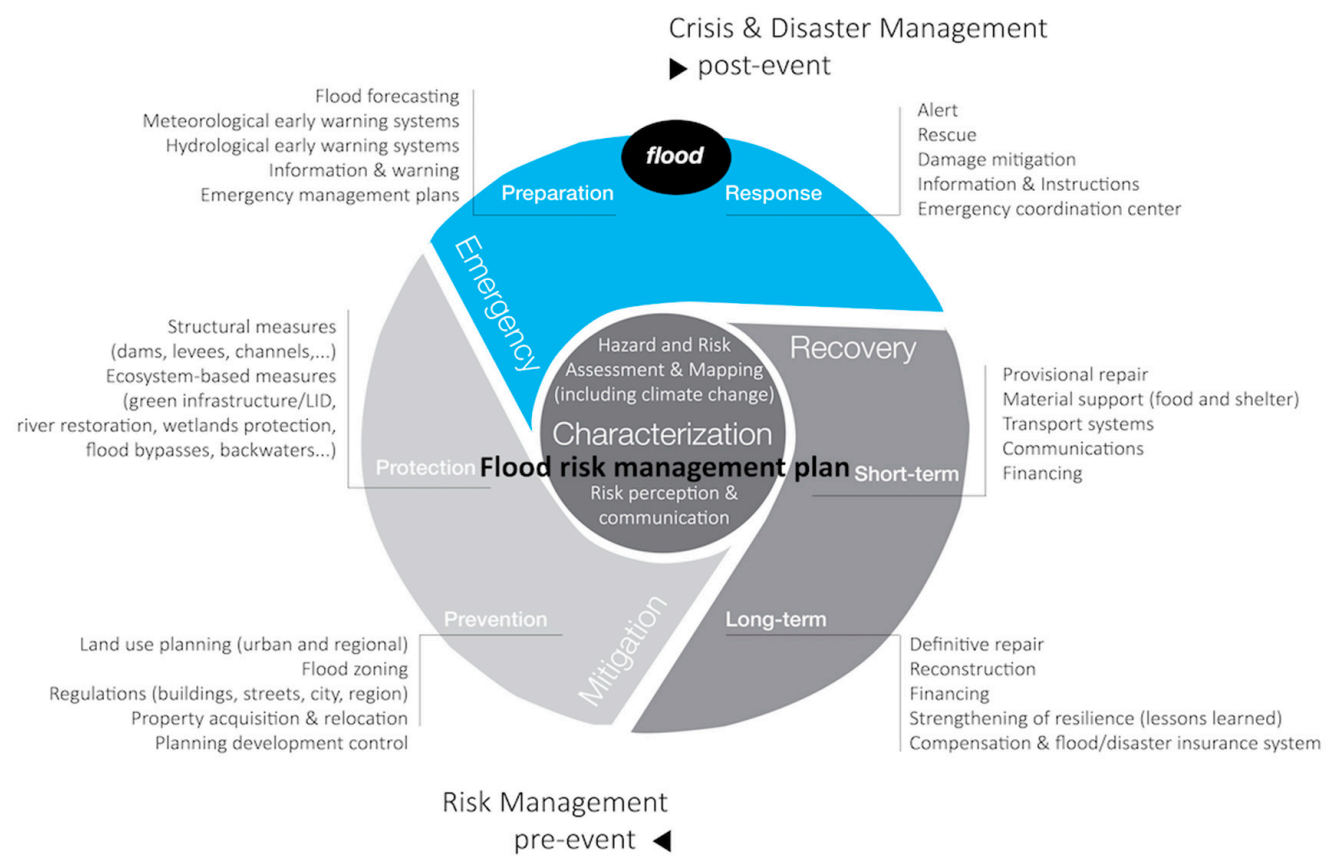

Figure 1. The flood risk management cycle. Source: Created by the authors, adapted from references $[25,26]$ and the concepts of G.F. White [28].

\section{Materials and Methods}

We reviewed policy documents and literature to compare IWRM as implemented in the EU under the Water Framework Directive (WFD) and Floods Directive (FD), with national, state and regional-level IWRM efforts in the US. We then identified two case studies for a detailed examination of the implementation of IWRM and flood risk management actions: The Catalan coastal region around Barcelona, Spain, and the San Francisco Bay region in California, US. These two regions were selected because they have similar climatic and socio-economic characteristics (described later in this section), but very different governance structures.

To compare the flood risk in both areas we analyzed data from official reports of the Department of Water Resources in California and the Directorate General of Civil Protection in Catalonia. There were no official numbers of estimated potential economic losses and number of people in flood prone areas in the Catalan River Basin District, so we compiled data at a municipal scale for the 635 municipalities included in the Catalan River Basin District.

To understand how IWRM and flood risk management have been implemented in these regions, we examined all the reports related to the Catalan River Basin District (Water) Management Plan and the Catalan River Basin District Flood Risk Management Plan, both completed in 2015, and the San Francisco Bay Area Integrated Regional Water Management (IRWM) Plan ("SF Bay Plan"), completed in 2013 (note that California's Integrated Regional Water Management program is abbreviated IRWM, while the broader concept of Integrated Water Resources Management is referred to as IWRM). We reviewed the WFD and FD and national water legislation and conducted a more detailed review of each plan, specifically of content related to the four phases of flood risk management. We also conducted a specific analysis of flood-related projects for the SF Bay Plan and the flood risk management measures described in the Catalan River Basin District Flood Risk Management Plan. We reviewed governance structures, guidance documents, and mapping products in both regions, with specific reference to who has participated in the process, and how the four stages of the flood risk management cycle have been addressed.

We conducted three face-to-face semi-structured interviews with staff from the Catalan Water Agency in Barcelona, supplemented with details via email exchanges with key government 
officials, and four semi-structured phone interviews with representatives of agencies involved in the development of the SF Bay Plan. The interviews were aimed at clarifying the process through which these plans were created, and to determine how they integrated each stage of the flood risk management cycle. Of the texts reviewed for Barcelona, most of the documents were in Catalan or Spanish, the native languages of the lead author. Interviews with Catalan officials were in English and Catalan. We manually coded transcripts of all interviews for themes related to flood risk management. While phone interviews in the Bay Area could not convey all the nuances of face-to-face interviews, the co-author had attended three Bay Area IRWM meetings and met all interviewees in person. This paper is also informed by a larger study conducted by one of the authors (Conrad) of the California IRWM process as a whole [29].

\subsection{Catalan and California Study Area Descriptions}

The Catalan coastal region around Barcelona, Catalonia, Spain, and the San Francisco Bay region around San Francisco, California, US, are both administrative regions for implementation of IWRM, and include densely settled coastal and estuarine urban areas and drainages from nearby coast ranges (Figure 2). Both regions exclude large inland river basins that traverse the coastal region but whose inland basins fall in different administrative regions (the Ebro River in Catalonia, the Sacramento-San Joaquin in California). These coastal Catalan and San Francisco Bay regions lend themselves well to comparison by virtue of their similar sizes and populations, similar topography, climate, and consequent nature of the flood hazards, and history of water resources development. Furthermore, the highly variable hydrological regime that characterizes Mediterranean climate-rivers [6] and the rapid urbanization in recent decades along the coast in both regions give these areas among the highest flood risk in Europe and North America [30-32]. The steady increase in catastrophic flood losses in Catalonia is evidently due not to an increase in rain intensities or amounts, but rather is related to increased human occupation of flood prone areas [33]. However, climate change threatens to increase the intensity and frequency of extreme hydro-meteorological events in the Mediterranean region [34].

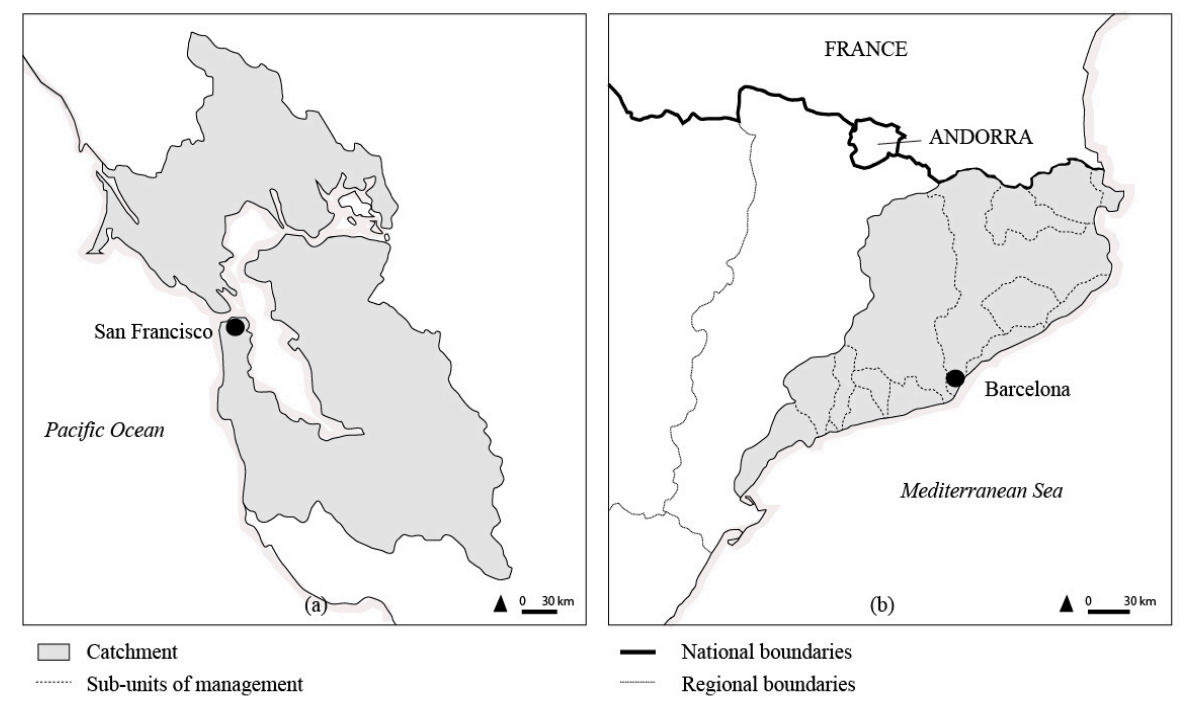

Figure 2. Location map: (a) the San Francisco Bay Area Integrated Regional Water Management Region; (b) the Catalan River Basin District with the 15 sub-units of management (areas of potential or significant flood risk).

The Flood Emergency Plan for Catalonia (INUNCAT) [35] includes an annex showing estimated populations and infrastructure exposed to flood risk by municipality. Summing these values for all 635 municipalities within the Catalan River Basin District yields over 360,000 people and 70 million euros in infrastructure. However, the Emergency Plan [35] warns that these numbers should 
not be taken as accurate, only as an indication of overall risk due to limitations in the data, and in our compilation of values from the 635 municipalities within our study area we found numerous municipalities without data. The maps published with the Emergency Plan [35] clearly show a greater exposure to flood risk in coastal areas. The San Francisco Bay Area is also subject to significant flood risks, which will likely be exacerbated due to sea level rise [36]. In 2013, an estimated one million people and $\$ 130$ billion in infrastructure were exposed to flood risk [37]. However, the regions differ sharply in the institutions and policies in place to implement IWRM and manage flood risk (Table 1).

Table 1. Characteristics of the two case studies: The Catalan River Basin District and the San Francisco Bay Area IRWM Region.

\begin{tabular}{|c|c|c|}
\hline Study Area & Catalan River Basin District (Catalonia, Spain) & San Francisco Bay Area IRWM Region (CA, US) \\
\hline $\begin{array}{l}\text { Overarching } \\
\text { program }\end{array}$ & $\begin{array}{l}\text { EU-Water Framework Directive (2000) } \\
\text { EU-Floods Directive (2007) } \\
\text { Top-down approach, obligatory }\end{array}$ & $\begin{array}{l}\text { DWR-Integrated Regional Water } \\
\text { Management Program (2002) } \\
\text { Bottom-up approach, voluntary }\end{array}$ \\
\hline $\begin{array}{l}\text { Boundaries } \\
\quad(\text { area })\end{array}$ & $\begin{array}{l}\text { Catchment boundary }\left(16,428 \mathrm{~km}^{2}\right) \text { for integrated } \\
\text { water management since } 1929, \\
15 \text { sub-units of management since } 2011\end{array}$ & $\begin{array}{l}\text { Catchment boundary }\left(17,770 \mathrm{~km}^{2}\right) \text { for integrated } \\
\text { water management since } 2004\end{array}$ \\
\hline Population & $\sim 7$ million inhabitants & $\sim 7$ million inhabitants \\
\hline \multirow{4}{*}{$\begin{array}{l}\text { Integrated } \\
\text { water } \\
\text { management } \\
\text { plan }\end{array}$} & $\begin{array}{l}\text { Catalan River Basin District Management Plan } \\
\text { (2009 first cycle, } 2015 \text { second cycle) } \\
\text { (536 pages + annexes) }\end{array}$ & $\begin{array}{l}\text { San Francisco Bay Area Integrated Regional Water } \\
\text { Management Plan (2006, updated in 2013) (963 pages) }\end{array}$ \\
\hline & Leading organization: Statutory Water Agency & $\begin{array}{l}\text { Leading organization: Coordinating Committee, } \\
\text { composed of } 14 \text { local water-related agencies and } \\
\text { non-governmental organizations }\end{array}$ \\
\hline & $\begin{array}{l}\text { Based on the WFD's goal: "Good ecological } \\
\text { status of all waters by } 2015^{\prime}\end{array}$ & $\begin{array}{l}\text { Based on } 5 \text { specific regional goals for the San } \\
\text { Francisco Bay Area IRWM Region: } \\
\text { "Promote environmental, economic and social } \\
\text { sustainability" } \\
\text { "Improve water supply reliability and quality" } \\
\text { "Protect and improve catchment health and function } \\
\text { and Bay water quality" } \\
\text { "Improve regional flood management" } \\
\text { "Create, protect, enhance and maintain environmental } \\
\text { resources and habitats" }\end{array}$ \\
\hline & $\begin{array}{l}\text { Budget: } 917 \text { M€ for } 6 \text { years (2015-2021) } \\
97 \mathrm{M} €(10 \%) \text { for flood projects }\end{array}$ & $\begin{array}{l}\text { Budget: } \$ 238 \mathrm{M} \text { (2004-2016; additional funding may } \\
\text { follow) (equivalent to } 211 \mathrm{M} € \text { ) } \\
\$ 163 \mathrm{M}(68 \% \text { ) for flood projects (equivalent to } 145 \mathrm{M} € \text { ) }\end{array}$ \\
\hline $\begin{array}{l}\text { Integrated } \\
\text { flood risk } \\
\text { management } \\
\text { plan }\end{array}$ & $\begin{array}{l}\text { Required: Catalan River Basin District Flood Risk } \\
\text { Management Plan ( } 2015 \text { first cycle) ( } 2 \text { main } \\
\text { documents: general measures ( } 119 \text { pages) + } \\
\text { hydrological measures ( } 80 \text { pages) + annexes) } \\
\text { Leading organization: Statutory Water Agency } \\
\text { Based on the Floods Directive's goal: "To reduce } \\
\text { and manage the risks that floods pose to human } \\
\text { health, the environment, cultural heritage and } \\
\text { economic activity" }\end{array}$ & $\begin{array}{l}\text { No specific flood risk management plan required, but } \\
\text { the region's flood risks and needs must be discussed } \\
\text { in the IRWM plan }\end{array}$ \\
\hline
\end{tabular}

\subsubsection{Catalan River Basin District, Catalonia, Spain (EU)}

The Regional Government, and in particular the Catalan Water Agency has full authority over water management for the Catalan River Basin District according to the Legislative Decree 3/2003 [38]. In Catalonia, water has been managed under this catchment boundary since 1929. It comprises an area of $16,428 \mathrm{~km}^{2}$ and includes 11 relatively small river basins draining the coastal ranges and debouching into the Mediterranean. From the French boarder south, these are the Rivers Muga, Fluvià, Ter, Daró, Tordera, Besòs, Llobregat, Foix, Gaià, Francolí, and Riudecanyes, along with smaller catchments and associated coastal waters [39]. These catchments have been reclassified into 15 flood risk management units, identified during the preliminary flood risk assessment in 2011, which correspond to the areas where potential significant flood risk exists (Figure 2b). The Catalan River Basin District represents only $52 \%$ of the territory of Catalonia, but because it encompasses Barcelona and other coastal cities, 
it supports $92 \%$ of the Catalan population (seven million inhabitants). Urban and industrial uses represent $65 \%$ of water consumption, with agriculture accounting for the rest [40]. The occupation of flood prone areas with new development along the coast has increased dramatically in Catalonia, especially during the second half of the 20th century [41], with the most rapid development occurring right before the economic crisis of 2008 [42,43].

\subsubsection{San Francisco Bay Area Integrated Regional Water Management Region, California (US)}

While the San Francisco Bay Area is considered as a single unit for some planning purposes, such as transportation, there has never been a regional planning authority with regard to water, which is managed locally by hundreds of cities, counties and special districts. The San Francisco Bay is an estuary, which receives runoff from the Sacramento-San Joaquin Rivers, as well as smaller coastal river draining the coastal ranges. The San Francisco Bay Area IRWM Region encompasses 17,770 $\mathrm{km}^{2}$, and includes the catchments of streams and rivers draining into three distinct "bays" within the estuary (San Francisco, San Pablo, and Suisun Bays). The San Francisco Estuary includes part of nine counties, three major metropolitan cities (San Francisco, San Jose, and Oakland), and 101 smaller cities and towns. It is the fifth largest metropolitan area in the US with a population of over seven million, and ranks as the world's 24th largest economy, fueled in part by high-technology industry in silicon Valley [44].

\section{Approaches to IWRM and Flood Risk Management in Spain and the United States}

\subsection{Flood Management and IWRM in Spain: Integrating the European WFD and the FD into the River Basin Confederations}

Spain has a long trajectory of water management at a catchment scale, which started in 1926 with the creation of the Hydrographic Confederations. These State-level organizations were in charge of the management of surface water, which in Spain is "public domain" [45]. With the new constitution of 1978, regions (Autonomous Communities) gained more power in Spain. Hydrographic Confederations continued being the principal organization that managed surface water in Spain, but were divided into two different types: (1) State-level Hydrographic Confederations: when the waters flow through only one Autonomous Community; and (2) Autonomous-level Hydrographic Confederations: When the waters flow through more than one Autonomous Community [46]. This is the case of the Catalan River Basin District, where a Regional Government agency, the Catalan Water Agency, has full authority on water management. In Spain, groundwater was private property until 1985, when a new Water Act recognized that both surface and groundwater were part of the same water cycle so they should be managed under the same plan at a river basin scale. The first attempts at integrated flood risk management appeared in Spain after the catastrophic Tous Dam break in Valencia in 1982, which triggered a radical change in the way floods were managed [47]. For first time, non-structural measures such as land use planning, flood risk mapping, early warning systems and a coordinated public flood insurance system were used.

However, it was not until the recent transposition of the WFD (2000), and the FD (2007) into national law that water management and floods risk management had to be planned in an integrated and coordinated way. The WFD represented a radical reform of water legislation in the EU [48]. Under the WFD all member states had to constitute competent authorities at the river basin scale to carry out river basin assessments, to identify objectives, and define programs of measures, such that all river basins should achieve good quality status by 2015 . The program of measures was to be iteratively evaluated in updates every six years, building on the river basin management plans, first submitted in 2009 and to be improved in subsequent cycles. The WFD also added ecological values to the concept of IWRM, until then neglected in the Spanish approach, and required a public participation process, involving a range of sectors, NGOs and the public [48].

Although Spain had a long tradition in managing floods at a river basin scale the implementation of the WFD added a new definition of the unit of management. It described the river basin "districts" 
as the area of land and sea, made up of one or more neighboring river basins together with their associated groundwater and coastal waters (Article 3(1)) [49]. This new concept, wider than the prior Spanish definition, made it necessary to include transitional and coastal waters in the Spanish river basins, which previously had only included surface and groundwater [46]. This created some problems due to the contradictory definitions of the unit of management, as coastal jurisdiction has been a State-level role. To comply with requirements of the WFD, Spain had to re-arrange the river basin districts and set up a new organization between the Autonomous Community and the State, which was politically sensitive given the history of tensions between the State and Autonomous Communities about the control of water.

The FD must now be implemented within the WFD, so flood risk management plans must be developed by the same competent authorities established to develop and implement the WFD river basin management plans [46]. For the Catalan River Basin District, the competent authority is the Catalan Water Agency. This created some conflicts with other organizations, because in Catalonia flood "risk" was previously managed by the Directorate General of Civil Protection. Furthermore, the integration of the flood risk management plans within the WFD framework had profound implications for how flood risk management was to be implemented, especially in requiring that ecological values be considered in flood risk management. For example, the inclusion of hydromophological elements in the definition of good ecological status implied a shift in thinking about managing floods, because conventional structural measures typically result in simplification of channel form, resulting in loss of hydromorphological and ecological quality [50]. Thus, non-structural measures or soft structural measures for flood risk management, such as land-use controls, and river and floodplain restoration, are favored under the WFD [51].

In 2015 member states presented their second river basin management plan to the EU, as required by the WFD. One key improvement over the prior (2009) plans was the requirement that the 2015 river basin plans incorporate for first time flood risk management plans taking into account the whole cycle of floods, also at a river basin scale, as required by the FD [52]. This plan is based on a preliminary assessment of riverine and coastal areas at risk of flooding, as of 2011. For such zones, flood hazard and risk maps were drawn up in 2013. These maps subsequently served as the cornerstone of the flood risk management plans.

\subsection{Flood Management and IWRM in the US: National and State-Level Initiatives}

While the federal government plays an important role in some aspects of water management in the US, particularly in the construction of major flood management and water supply projects, most legal authority and responsibility for water management lies at the state and local levels [53]. With an estimated 100,000 local agencies dealing with water issues and 300 state-level agencies, many with narrowly-defined and sometimes conflicting missions, the US has suffered from a lack of coordination among policies, and between policy and implementation, with respect to water supply, water quality, and flood related issues [54]. For example, in the context of flood management, local land-use agencies have permitted residential developments within designated flood bypasses that are integral components of the federal flood control system on the Mississippi River [55].

As the concept of IWRM gained currency in the 1990s, water managers at federal, state and local levels began to recognize the need for greater coordination, particularly at a catchment scale. While no formal national-level policies exist to promote IWRM, some federal agencies, such as the US Army Corps of Engineers, have begun to articulate their work within the context of IWRM [56]. In addition, the concept has influenced approaches to water management in a number of states [11]. The state of California has gone further than most in formally promoting the practice of IWRM through state grant programs, and thus offers a good context for studying its implementation in the US, and for comparison with the EU.

In 2002, the California State Legislature created the Integrated Regional Water Management program (IRWM), designed to encourage local water agencies to collaborate with one another to 
develop regional-level water management plans that integrate all aspects of water management. The program emerged out of a recognition that amidst growing water demands and an increasingly uncertain climate, infrastructure-based strategies alone could no longer be relied upon to meet water needs, and "integrated" strategies addressing multiple dimensions of water management were essential. The program's creators were also influenced by IWRM principles, emphasizing the importance of holistic management at the catchment scale, and the need to engage a broad range of stakeholders in the process [29]. The IRWM program represented an effort to overcome the long-standing fragmentation of water management responsibilities in California, where over 1000 special districts, cities and counties hold authority over various aspects of water supply, irrigation, sanitation, and flood management [57]. In particular, flood management and water supply activities have long been managed through separate agencies and processes. In addition, building effective linkages between land use activities and water planning has been an on-going struggle in California, as elsewhere in the US [58].

The 2002 IRWM Planning Act established a process whereby local agencies could form a "region" and jointly prepare an integrated plan for managing their water resources, referred to as an IRWM plan. The region was then eligible to receive funding to implement projects under IRWM plans, through grants financed by state bonds passed 2002-2014 and administered by the California Department of Water Resources (DWR). Between 2002 and 2014, a total of $\$ 2.31$ billion has been allocated to advance planning and projects under the IRWM program [59]. Access to these grant funds provided the incentive for local agencies to participate and form IRWM regions. DWR encouraged regions to form along catchment boundaries, but in keeping with California's long-standing tradition of local control over water resources, program requirements allowed local agencies to self-organize around their preferred regional boundaries. By 2012, 48 IRWM regions had been created, covering 87 percent of the state's area and ranging in size from 680 to over $50,000 \mathrm{~km}^{2}$ [60]. About a quarter of all regions follow catchment boundaries, but most are formed along a combination of catchment, groundwater, or jurisdictional lines [29]. Grant program requirements encourage diverse participation, and in fact require that regions reach out to a list of thirteen specific types of stakeholders.

The goal of the IRWM program was not simply to provide project funding. Instead, the process of writing IRWM plans and developing joint grant proposals was intended to encourage local agencies and non-governmental organizations to begin to understand each others' needs, identify common priorities, and learn to work with one another. As one state official involved in designing the IRWM program commented, "A big part of this is changing a culture, and how we look at me, my neighbors and my regions, and how to solve problems" [29].

Despite the program's goals to integrate all aspects of water management, the IRWM program is not the only forum in which flood management activities are developed and implemented. In 2006, spurred by increased awareness of flood risks after Hurricane Katrina in 2005, California voters approved $\$ 4$ billion in bond funds to improve flood protection in the state. These funds supported a range of programs, together referred to as FloodSAFE California. Of this $\$ 4$ billion, only $\$ 300$ million was allocated to stormwater management and flood protection projects developed by IRWM regions (this is included in the $\$ 2.31$ billion for 2002-2014), and the remaining $\$ 3.7$ billion has been spent through other programs and projects, particularly in the Central Valley, which faces the highest flood risks in the state. These resources have supported implementation of the Central Valley Flood Protection Plan, which involves coordination between federal, state and local agencies, who have shared responsibility for existing dikes, dams and other flood management infrastructure [61]. However, the coordination between different levels of government needed to respond effectively to large floods (of the scale of hurricane Katrina) has not been achieved. The lack of complete integration of flood management activities with the IRWM program stem in part from its voluntary character, which does not provide an appropriate setting for federal, state and local agencies to fulfill their responsibilities to maintain flood infrastructure so as to provide legally mandated levels of flood protection [62]. 


\section{Results}

In this section, we discuss how IWRM and flood risk management efforts have been operationalized in our two case studies, and analyze how implementation has been shaped by their distinct "top-down" versus "bottom-up" governance approaches. Table 2 summarizes the key differences we documented between these approaches with regard to four aspects: (1) institutional setting; (2) approach to flood risk management and IWRM; (3) governance systems, particularly with regard to coordination and participation; and (4) the capacity to adapt to change.

Table 2. Main differences between top-down and bottom-up governance approaches in the two case study regions.

\begin{tabular}{|c|c|c|c|c|}
\hline $\begin{array}{l}\text { Governance } \\
\text { Approach }\end{array}$ & Institutional Context & $\begin{array}{l}\text { Approach to Flood Risk } \\
\text { Management and IWRM }\end{array}$ & $\begin{array}{l}\text { Governance System } \\
\text { (Coordination and } \\
\text { Public Participation) }\end{array}$ & $\begin{array}{c}\text { Capacity to } \\
\text { Adapt to Change }\end{array}$ \\
\hline $\begin{array}{l}\text { Top-down } \\
\text { (EU/Catalan } \\
\text { River Basin } \\
\text { District) }\end{array}$ & $\begin{array}{l}\text { Acceptance of state } \\
\text { and regional authority } \\
\text { over water planning. } \\
\text { Subject to goals and } \\
\text { timeframes (WFD and } \\
\text { FD) common to all } \\
\text { river basins } \\
\text { districts in the EU. } \\
\text { Planning must be at } \\
\text { river basin } \\
\text { scale-15 sub-units of } \\
\text { management for the } \\
\text { Catalan River } \\
\text { Basin District. }\end{array}$ & $\begin{array}{l}\text { Must coordinate all flood } \\
\text { risk management efforts } \\
\text { with IWRM effort (river } \\
\text { basin plan under WFD). } \\
\text { Flood risk assessment and } \\
\text { mapping conducted at } \\
\text { river basin scale. } \\
\text { Utilizes risk-based } \\
\text { approach to choosing } \\
\text { measures (flood risk } \\
\text { maps guide selection } \\
\text { of projects). }\end{array}$ & $\begin{array}{l}\text { Long history of river basin } \\
\text { scale planning, which has } \\
\text { facilitated coordination (led } \\
\text { by Catalan Water Agency). } \\
\text { WFD and FD requirements } \\
\text { have led to expanded } \\
\text { participation and } \\
\text { coordination between } \\
\text { different organizations in } \\
\text { the region in charge of flood } \\
\text { management. However, } \\
\text { local agency participation is } \\
\text { limited, primarily occurring } \\
\text { during the public } \\
\text { participation process. } \\
\text { Regional-level plans related } \\
\text { to flood management and } \\
\text { land use are being } \\
\text { coordinated, but future } \\
\text { enforcement is uncertain. }\end{array}$ & $\begin{array}{l}\text { Relatively stable funding } \\
\text { and presence of } \\
\text { a coordinating entity enables } \\
\text { focus on long-term. } \\
\text { However, financial problems } \\
\text { of the Catalan Water Agency } \\
\text { requires rethinking } \\
\text { future funding. } \\
\text { Required to consider climate } \\
\text { change in WFD and FD } \\
\text { planning processes. } \\
\text { 6-year planning cycle } \\
\text { promotes updating based on } \\
\text { new knowledge. } \\
\text { Participation may } \\
\text { generate new knowledge, } \\
\text { if ownership of process } \\
\text { is adequate. }\end{array}$ \\
\hline $\begin{array}{c}\text { Bottom-up } \\
\text { (California/ } \\
\text { SanFrancisco Bay } \\
\text { Area IRWM } \\
\text { Region) }\end{array}$ & $\begin{array}{l}\text { Long-standing norms } \\
\text { of local control over } \\
\text { water resources. } \\
\text { Common framework } \\
\text { at state level, but } \\
\text { allows regions to } \\
\text { define their own goals } \\
\text { and timeframes. } \\
\text { River basin/catchment } \\
\text { scale encouraged, but } \\
\text { regions can choose } \\
\text { own boundaries. } \\
\text { SF Bay IRWM follows } \\
\text { catchment boundary. }\end{array}$ & $\begin{array}{l}\text { All flood management } \\
\text { activities are not required } \\
\text { to be linked with the } \\
\text { IWRM effort (SF Bay Plan). } \\
\text { Flood risk assessment and } \\
\text { mapping not conducted at } \\
\text { regional scale. } \\
\text { FEMA continues to } \\
\text { provide flood maps to } \\
\text { local agencies for their use. } \\
\text { Does not utilize risk-based } \\
\text { approach to select projects. } \\
\text { Local agencies propose } \\
\text { projects for inclusion, } \\
\text { which are prioritized } \\
\text { based on multiple criteria. }\end{array}$ & $\begin{array}{l}\text { With no history of water } \\
\text { planning at regional scale, } \\
\text { no single entity existed to } \\
\text { facilitate coordination. } \\
\text { IRWM program } \\
\text { requirements have resulted } \\
\text { in expanded public } \\
\text { participation, and led to the } \\
\text { formation of new, } \\
\text { regional-scale network of } \\
\text { local flood managers. } \\
\text { Direct involvement of local } \\
\text { agencies helps ensure } \\
\text { ownership of } \\
\text { proposed projects. } \\
\text { Little coordination with land } \\
\text { use planning, at regional } \\
\text { and local level. }\end{array}$ & $\begin{array}{l}\text { Uncertain future funding } \\
\text { and lack of a coordinating } \\
\text { entity leads to } \\
\text { short-term focus. } \\
\text { IRWM plans are required to } \\
\text { discuss/incorporate climate } \\
\text { change impacts but FEMA } \\
\text { floodplain maps do not yet } \\
\text { incorporate climate change. } \\
\text { Periodic plan updates } \\
\text { promotes incorporation of } \\
\text { new knowledge, if funding } \\
\text { is available. } \\
\text { Participation is likely to } \\
\text { generate new knowledge } \\
\text { due to high level of } \\
\text { ownership of } \\
\text { proposed projects. }\end{array}$ \\
\hline
\end{tabular}

\subsection{Institutional Context}

\subsubsection{Catalan River Basin District}

In Catalonia, the regional government has a long trajectory of managing water at the catchment scale, beginning with the creation in 1929 of what is today the Catalan River Basin District. Recently boundaries have been modified to comply with the WFD mandates, as discussed in Section 3.1. The "top-down" approach to water planning and management has been further strengthened as a result of the WFD and FD. Both regulations have clear and specific goals and timelines, which must be implemented in all river basins. For example, flood risk management as an integrated part of water management did not begin until the implementation of the WFD and the FD. Following the main goal of the WFD, to achieve a good ecological status of all waters, the main objective of the Flood Risk 
Management Plan is to avoid increasing flood risk from existing levels, and to reduce it as much as possible in the areas with potential or significant flood risk, and it includes a set of specific objectives and measures that have to be implemented through specific actions.

\subsubsection{SF Bay Area}

In the San Francisco Bay Area, flood management aspects of IWRM are being implemented within a very different institutional context, with a strongly "bottom-up" character. California has a long history of local control over water management, and in the Bay Area, there are hundreds of local water agencies and cities with varying and often overlapping authority for managing water supply and floods. Thus, while the overall intent of the IRWM program is similar to that of the WFD-to encourage an integrated approach to water management-local agencies are not required to participate, but do so in response to the incentive of access to funding. In forming regions, local agencies were encouraged, but not required, to follow catchment boundaries. Further, the state's requirements for developing IRWM plans provided a common framework, but allowed each region to define its own goals and objectives. As a result of this voluntary, flexible approach, there is considerable diversity across the 48 IRWM regions as to their boundaries, goals, and approach to flood management.

Water agencies in the SF Bay Area chose to define their region along catchment boundaries, coinciding with the San Francisco hydrologic region, one of ten, defined by the state [37]. They did this in part because some of the agencies had worked together previously, but there was also a financial incentive to do so. The state distributes IRWM funding at the hydrologic region scale, and if an IRWM region covered that entire area, it would not have to compete against other regions for that funding. The SF Bay Area is one of only three IRWM regions across the state that chose to take advantage of this incentive; the other 45 regions formed at smaller scales and must compete for funding [12].

The state's requirements for IRWM plans are relatively broad, defining key topics that must be covered-including flood management-but allowing considerable flexibility in defining goals, objectives, and timelines [61]. The SF Bay Plan included flood management as one of its five "over-arching goals" (Table 1), which encompass water supply and quality, watershed health, flood management, protection of environmental resources, and overall sustainability. Under the flood management goal, the plan includes six "basic strategies" for flood management [19]:

- Integrated flood management and land use

- Leverage natural watershed features

- Adopt a "best mix" of structural and nonstructural approaches

- Implement regional flood management at a system scale

- Promote multiple benefits

- Implement multiple-hazard management

IRWM regions must include performance metrics in their plans, but these look very different across regions. The SF Bay Plan's performance metrics relate not to measures of progress toward reduced flood risk or increased reliability of water supply, but instead focus on whether projects are being implemented and monitoring whether the objectives of specific projects are being achieved [19]. Overall, in the SF Bay Area a "bottom-up" approach has resulted in a relatively broad set of goals, strategies and metrics that allow considerable flexibility for local agencies to advance their own priorities.

\subsection{Approach to Flood Risk Management and IWRM}

\subsubsection{Catalan River Basin District}

The measures included in the flood risk management plans are based on a previous risk analysis at a catchment scale, following requirements of the FD. However, there is a highly variable relationship between the ideational and procedural elements of the risk-based governance when looking at different EU countries [63]. The risk analysis in the Catalan River Basin District was undertaken in discrete steps 
according to the FD. First (in 2011), the Agency identified fifteen areas, that include 72 reaches of river and floodplain (about $447 \mathrm{~km}$ in length) and 28 coastal areas with potential or significant flood risk, based on existing data and historical flood maps [39]. Second (in 2014), the Agency created multiple detailed flood hazard maps and coordinated, with the the Directorate General of Civil Protection, flood risk maps for each risk area (to be updated every six years). The flood hazard maps include three scenarios: 10, 100, and 500-year floods (designated as high, medium, and low probability), and for each scenario they show three ranges of water depths: $<40 \mathrm{~cm}, 40-100 \mathrm{~cm}$, and $>100 \mathrm{~cm}$. The Directorate General of Civil Protection combined maps of flood prone areas (described above) with land-use maps, so the resources vulnerable to flooding (population, economic activities, environment) could be readily determined. For coastal areas, the Coastal Demarcation, a State-level organization, created maps for the 100- and 500-year events (medium and low probability), but these maps do not distinguish between different land uses threatened by coastal flooding. The FD also requires development of maps showing future flood risk, but there is currently inadequate information about future socio-economic and climate changes to create these maps with confidence.

These maps are critical for all the phases of flood risk management, including prohibition of building within the official floodplain, which in Spain is the 500-year floodplain [42]. While implementation has yet to begin in earnest, in Spain, as elsewhere, enforcing such land-use restrictions at a local scale has proved challenging [42]. Similar problems are experienced in other countries such as the UK [64]. The probability maps are also used by the Directorate General of Civil Protection to define municipalities at medium low, moderate, medium, high, and very high risk of flooding. Municipalities with medium or greater flood risk must create local emergency plans [35]. The website of the Directorate General of Civil Protection includes these three scenarios, plus the area of the maximum ordinary flood, the 10 and 50 year flood probability maps, and a residual risk map of potentially flooded areas, which are 500 year flood probability maps according to geomorphological features only, i.e., what areas would flood if dikes failed.

The third step (2015) involved creating a flood risk management plan for the Catalan River Basin District by setting up objectives and developing a Program of Measures, which now is being implemented through specific actions. The plan includes measures across the cycle of flood risk management (Figure 1): Territorial and urban planning measures for prevention; hydrologic, river restoration, and coastal measures to increase protection; civil protection measures for emergency management and short-term recovery; and measures to promote insurance as a tool to long-term recovery. Each measure is classified as high, medium or low priority taking into account its importance in solving a specific issue, the cost-benefit analysis, the impact in other measures, especially the impact on achieving the environmental water goals of the WFD.

\subsubsection{SF Bay Area}

Unlike in Catalonia, not all flood management activities in California are coordinated with the IRWM process, in part due to the program's voluntary nature. The SF Bay Plan focuses primarily on the flood mitigation phase of the flood risk management cycle. It does not include regional-scale flood risk mapping. Flood maps in the US are actually Flood Insurance Rate Maps, not flood "risk" maps, and are undertaken by the Federal Emergency Management Agency (FEMA) under the National Flood Insurance Program (NFIP). These maps are used at the local scale by municipalities to zone developments and to determine whether property owners are required to purchase flood insurance. The SF Bay Plan mentions this process, but does not seek to play a role in it, or utilize floodplain maps to prioritize IRWM projects for funding.

Instead, the identification and prioritization of projects to implement the SF Bay Plan is guided by a broader set of criteria and is driven by local interests. Once the plan's overarching goals and the basic strategies were developed, the Coordinating Committee-a committee 10 representatives of agencies involved in the process-held an open "call for projects". Any governmental or non-governmental entity in the Bay Area could propose a project that would support plan implementation. The submitted 
projects were then reviewed and ranked according to criteria that included whether or not they would help address the region's goals, were technically feasible, whether it addresses the needs of disadvantaged communities, and more [19]. In proposing projects related to flood risk, local entities would have typically consulted flood maps produced by FEMA, but the process was not designed to prioritize projects according to the degree of flood risk at the regional level.

Ultimately, the plan included a prioritized list of 315 projects to meet regional needs. The on-going work of the San Francisco Bay Area IRWM region is to seek funding to undertake these projects, through the IRWM funding process, as well as other avenues. For each funding round, the Coordinating Committee decides which projects to include in a particular grant proposal. Top-ranked projects are more likely to be included, but other factors such as the availability of matching funds are also considered. As of 2016, the San Francisco Bay Area IRWM region had received over \$163 million from bond funds for 28 projects that we identified as flood-related, based on our analysis of project descriptions. Many projects were multi-objective, and most received only part of their total funding from the DWR IRWM funding. For example, the Milliken Creek Flood Damage Reduction and Fish Barrier Removal in Napa County, received $\$ 0.5 \mathrm{M}$ of its total \$1.4 M cost through IRWM.

This high level of local co-financing demonstrates that the projects implemented as part of the regional plan have strong local ownership, as might be expected through a "bottom-up" approach. At the same time, relying on local leadership to propose and co-finance projects means that parts of the Bay Area with limited resources will have more difficulty proposing projects for inclusion, and obtaining IRWM funding to implement them. Flood risks tend to be highest in lower-income communities, particularly as sea level rise exacerbates local flooding [36]. Thus, this bottom-up process may not ensure that the most serious flood risks are being addressed. The IRWM program tries to address this by setting aside $10 \%$ of project funding statewide for projects in low-income communities, and by waiving the requirement for local matching funds [65]. However, significant barriers remain for low-income communities to propose and receive funding for projects through the IRWM process [12].

\subsection{Governance System (Coordination and Public Participation)}

\subsubsection{Catalan River Basin District}

Coordination is a critical aspect of the implementation both the WFD and FD (Articles 8 and 9). The Catalan Water Agency is the competent authority to implement the WFD in the Catalan River Basin District (Table 1). Because flood risk management plans must take into account the entire cycle of flood risk management (Figure 1), the plan development must include all actors involved in flood management at different governance scales. Figure 3a summarizes the main organizations in charge of the different phases of flood risk management in the Catalan River Basin District. The flood risk management plan must be coordinated not only with the river basin management plan, but also with other existing plans related to flood management. These include the general emergency plan of Catalonia, the special emergency plan for flood risk of Catalonia, the local emergency plans, the industries emergency plans, the dams emergency plans, and also other flood-related protocols such as early warning systems.

To encourage public participation, the Catalan Water Agency invited 5000 actors involved in water management in the region (such as NGOs, water agencies, local water departments, and private water purveyors) to meetings to provide input into the decision-making process for the measures [39]. However, the participation of local actors was minimal. The final plan took into account the suggestions of the participants in the public process and was available online for a three-month comment period. The final documents (including public comments) are publicly available on the website of the Catalan Water Agency [39]. Across Europe, the processes used for public participation and the degree of engagement of local stakeholders varied widely [66]. The degree of stakeholder involvement can have strong implications in the degree of ownership of flood-related projects and in the progress towards 
adaptation strategies to cope with climate change, since many of its impacts will be experienced at a local scale [67].

\subsubsection{SF Bay Area}

Since there is no single, regional-scale agency responsible for flood planning or other aspects of water management in the SF Bay Area, local agencies had to organize themselves to create a means for working together on the IRWM plan. In 2004, 19 local water districts, cities and county agencies signed a memorandum of understanding to work together, and formed a Coordinating Committee to govern the process of developing and implementing plans. In addition to a chair and co-chair, this committee includes three representatives each of the agencies involved in the following four "functional areas" of water management: water supply/quality, wastewater/recycled water, flood and stormwater management, and catchment/ecosystem protection. This structure reflects the fact that prior to the IRWM process, water supply agencies had already organized themselves into several networks, one focused on water supply and quality issues (the Bay Area Water Agencies Coalition), and wastewater and sanitation (the Bay Area Clean Water Agencies). The committee did not assume regulatory authority over the four phases of flood risk management; such a step would have met with strong resistance. While local entities with land use authority do participate in the process, this is motivated by the availability of funding for projects related to the flood mitigation phase. There has been no involvement by representatives of emergency management and recovery, such as the FEMA, insurance companies, and the US Army Corps of Engineers (see Figure 3b).

IRWM program guidelines also required regions to conduct extensive outreach in the development of IRWM plans, particularly for the 2013 update [65]. Coordinating Committee members, with the help of consultants, hosted sub-regional meetings to discuss water management needs and project ideas, and held numerous public meetings. The region's stakeholder engagement involved a diverse group of water supply, water quality, wastewater, stormwater, flood control, catchment, municipal, environmental, and regulatory groups. This included representatives from federal, state, and local water resource and regulatory agencies, non-governmental organizations-in particular those NGOs that represented disadvantaged communities, and the general public.

Given its voluntary character, the way in which the IRWM process can influence the practice of floodplain management is not through plan requirements, but rather through increased dialogue and knowledge exchange among land use and water management stakeholders, which may lead them to identify new ways of working together on a voluntary basis. Our research indicates that IRWM program did contribute to the formation of new connections between flood managers in the Bay Area. Prior to the IRWM program agencies involved in flood management and ecosystem protection had not been formally organized. The need to represent these interests in the IRWM Coordinating Committee led to the creation of the Bay Area Flood Protection Agencies Association, which has become an active forum through which local flood managers work together. In addition, an informal network of public and non-profit agencies was created to lead the catchment protection functional area [12].

However, with regard to building working relationships and integrating the activities of across different aspects of water management and land use, research suggests that the IRWM process in the Bay Area has had only a limited effect [68]. One example of this is the way in which land use planning is integrated with the IRWM plan. Local land use entities such as cities and counties do participate, but are not required to alter their local land use plans to take the goals of the IRWM plan into account. They continue to utilize the flood maps produced by FEMA, the federal agency responsible for flood mapping, but FEMA is not extensively involved in the IRWM process (Figure 3b). There is a separate regional planning process, called "Plan Bay Area", which seeks to concentrate new development at transit "hubs". However, due to limited coordination between the IRWM process and the Plan Bay Area, many of these new transit hubs are on floodplains and highly vulnerable to flooding. Thus, the land use priorities advanced in the name of one socially desirable objective (increased use of public transit and reduced reliance on automobiles) run against the efforts to minimize flood risk. 


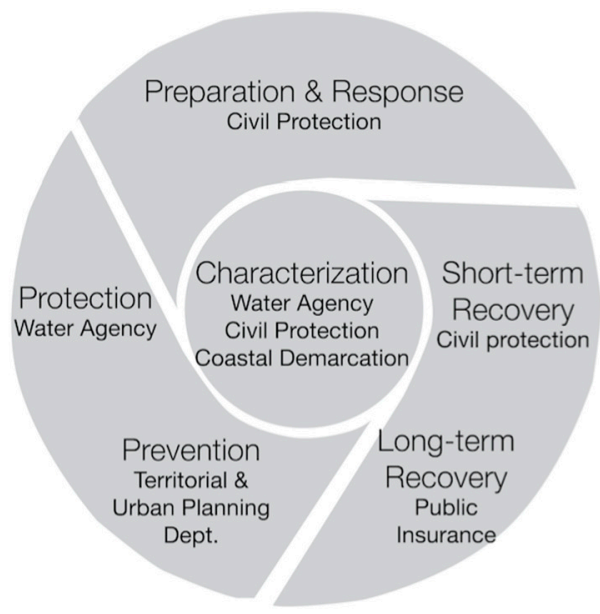

(a)

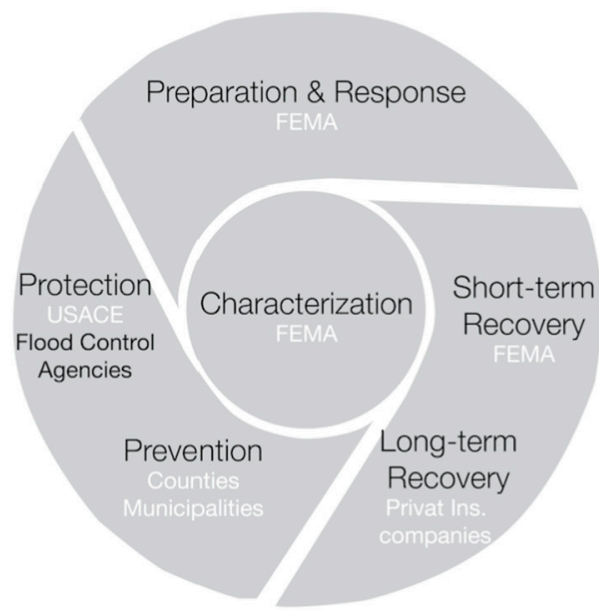

(b)

Figure 3. Main organizations in charge of the different phases of flood risk management in (a) the Catalan River Basin District; and (b) the San Francisco Bay Area IWRM Region. In white organizations working on flood-related issues in the San Francisco Bay Area but that did not participate in the creation of San Francisco Bay Plan.

\subsection{Capacity to Adapt to Change}

Research has suggested that adaptive governance arrangements must have systems in place to access and incorporate into decision-making new knowledge about changes in the climate, socio-economic conditions, and ecological systems, and lessons learned through policy implementation [8]. "Bottom-up" arrangements are often viewed as being better able to support the necessary learning than are "top-down" ones, since collaboration among a wide range of stakeholders can bring diverse forms of knowledge to bear directly in the decision-making process [5]. However, building upon Huntjens [9,20], our comparison of the Catalan coastal region and the SF Bay Area suggest that some features of "top-down" approaches can also have value in this regard.

As described in previous sections, implementation of the WFD and FD in Catalonia has led to the expansion of public participation in what was already a river basin scale planning process. This suggests that the planning process has potentially gained access to new inputs of knowledge from a wider range of interests. Whether or not this knowledge informs the plan and its implementation depends upon how the Catalan Water Agency, which is ultimately responsible for overseeing the plan, structures the participation and builds ownership among agencies whose cooperation is required to implement the plan. The development of the 2015 plan appears to have been informed by input from diverse participants, but it is uncertain as to how implementation will proceed. Has participation in the process built new relationships between land use and other entities that will support on-going information-sharing during implementation? Will lessons learned from this first phase inform the update of the plan six years later? Additional research will be needed in the coming years to address these questions.

If participation does lead to the creation of new networks, Catalonia's top-down approach has a few other features that would seem to support adaptive governance. The EU requires that plans under the WFD and FD be updated every six years, which provides an on-going structure for reviewing and incorporating lessons learned and the current state of scientific knowledge. The FD requires that climate change be accounted for in flood risk assessments and maps, which better enables planning for future extremes. Furthermore, funding is in place for the first six years, and includes considerable support (630 out of $917 \mathrm{M€}$, or approximately two-thirds) from the regional government [69]. Water users, local governments and the state government also share in the cost, and additional sources of funding are available through the EU. Ten percent of the budget is dedicated to 
flood risk management, amounting to $97 \mathrm{M} €$. This provides a clear budget for the first six years, and given that on-going planning will be required by the EU beyond that time period, continued funding is likely. These funding arrangements, accompanied by a clear on-going role for the Catalan Water Agency in continuing to manage the process, provide a degree of stability that enables more long-term thinking. However, financial problems of the Catalan Water Agency will necessitate rethinking funding sources in future cycles.

The SF Bay IRWM process bears out some of the expectations in the literature about the benefits of a "bottom-up" approach for adaptive management $[15,16]$. The Coordinating Committee itself is composed of local agencies, who bring their own knowledge to bear in the planning process and play a strong role in determining how projects are prioritized and selected for implementation. In addition, because local agencies needed to represent the interests of the flood management community on the Coordinating Committee, a new regional network of flood managers was formed. This network promotes on-going dialogue even outside of activities related to the plan. Finally, there is a high degree of local ownership over projects that receive funding, and therefore a considerable potential that local entities can contribute knowledge gained through implementation to inform future efforts.

However, the decentralized nature of the Bay Area's IRWM process may also pose difficulties for adaptation. Similar to the EU, IRWM guidelines in California also require that plans be updated periodically. However, they do not set specific timeframes for updates, leaving it up to regions to determine when updates are needed. IRWM plans are required to address climate change; and the state government has provided guidance on a basic vulnerability assessment that all regions must conduct [65]. However, this does not include quantifying how changes in sea level rise and extreme precipitation events will affect flood risks. FEMA's floodplain maps, which are utilized for planning by local land use authorities, do not yet incorporate climate change, although FEMA has been studying the issue [70]. Furthermore, the IRWM process does not have a stable source of long-term funding. Funding so far has come from bonds that were approved by voters in statewide elections in 2002, 2006 and 2014, but future bond funding is uncertain. Since participation in this voluntary program is largely incentivized by access to this funding, it is not clear whether regional planning will continue without this incentive. Finally, since no regional entity exists in the Bay Area with the mandate and capacity to support on-going regional water planning, the future of the Bay Area's IRWM process is even more uncertain.

\section{Conclusions}

We examined two attempts to implement IWRM and flood risk management under similar climatic and hydrologic conditions, but with distinct institutional settings and governance approaches. The Catalonia region of Spain primarily represents a "top-down" approach, in which EU regulations through the WFD and FD determine its goals and timeframes for achieving them, and a single, central entity, the Catalan Water Agency, is responsible for implementation. The San Francisco Bay Area region in California, on the other hand, is "bottom-up" in that the IRWM process is voluntary and encourages government agencies to collaborate with one another and determine their own goals, objectives and timeframes. We find that in these distinct governance settings, there are considerable differences in how IWRM and flood risk management are operationalized. In Catalonia, due to its long history of regional planning and compliance with EU-wide requirements, all four phases of the flood risk management cycle are integrated into the IWRM planning effort and projects are prioritized based on regional flood maps, as required by the WFD and FD. In the SF Bay Area, the lack of a broadly accepted role for regional planning and the voluntary character of the state's IRWM program has meant that only certain flood management activities are being coordinated at a regional scale, and projects are not prioritized to address the region's most significant flood risks. On the other hand, the Bay Area's "bottom-up" style appears to have led to greater ownership of the process on the part of participating agencies, as compared to Catalonia where local water departments and agencies have played a more limited role. Finally, much of the current literature suggests that "bottom-up" structures 
have more of an ability to bring together diverse knowledge in ways that can actually be integrated into decision-making in an iterative manner $[8,19]$. However, our study suggests that some features of "top-down" arrangements can be critical for adaptive capacity. For example, we note that the SF Bay Area faces considerable uncertainty with regard to future financing and lacks a stable entity that is willing and able to take on regional coordination over the long term.

Our findings contribute to understanding what governance structures may be best suited to implement IWRM, especially in understanding relative merits of "bottom-up" vs. "top-down" approaches in supporting integrated management and adaptation. Overall, our research suggests the need for a balance between "top-down" and "bottom-up" approaches, consistent with the findings of Huntjens et al. [9,20] and Pahl-Wostl [15]. The SF Bay Area IRWM process appears to have generated new networks among stakeholders involved in flood management, as well as in watershed health, and has brought many local entities into dialogue with one another for the first time. This offers the potential for new learning and strong ownership of the process among participants. However, the lack of an entity with capacity to provide leadership on an on-going basis, accompanied by uncertain funding, makes effective long-term and iterative planning difficult. This capacity does appear to exist in the Catalonia case, in part because the "top-down" nature of the WFD and FD led to requirements for on-going planning at the river basin scale. However, whether or not the Catalonia case will generate new networks, dialogue, and knowledge sharing among participants in the planning process will depend upon how the Catalan Water Agency exercises its role in managing the process and encouraging participation. Research on "boundary" or "bridging" organizations suggests that the Catalan Water Agency would be most likely to promote learning and adaptation if it takes a facilitative, convening approach to its role as a central actor, actively promoting dialogue among participants rather than acting as a gate-keeper for the implementation process [71,72].

The "top-down" and "bottom-up" approaches employed in the two case studies are not so much the result of choices made during the inception of these IWRM efforts, but instead arose from long-standing institutional arrangements that favor one approach or another. Given California's long-standing pattern of local control over water, it would be difficult to impose "top-down" governance that would be perceived as legitimate, no matter what benefits it might offer. In Catalonia, engaging in a collaborative style of management in which decision-making is shared between regional and local entities might be equally hard to initiate, despite the learning it might generate. Nonetheless, the SF Bay Area and Catalonia have something to learn from one another in implementing IWRM. Institutional change is often incremental [73], and these contrasting experiences with flood risk management and IWRM could spark ideas for smaller changes that might be feasible to introduce. For example, Catalonia's experience suggests the value of regional-scale flood risk mapping for identifying areas with the highest levels of flood risk. Thanks to the "top-down" approach in that region, the regional water agency is able to use these maps to prioritize which flood risk measures should be implemented. Although the current institutional setting in the Bay Area may not currently permit the direct use of regional flood maps to prioritize projects, the Coordinating Committee could still decide to create and distribute such maps as a resource. While local agencies would not be required to utilize it, they might find it to be a valuable tool that they would not have been able to produce themselves, and over time it may gain relevance in decision-making. Catalonia can also draw lessons from the Bay Area's strong ownership of the process among the local agencies involved, and the value of the horizontal networks it has generated. The Catalan Water Agency, while retaining its authority over water management in the region, could seek to convene local agencies at multiple phases in the planning process, and potentially help to create similar horizontal networks. Actors involved in IWRM and flood risk management in other settings, particularly in Mediterranean climates where extremes in rainfall are already common, and are likely to be further exacerbated by climate change.

There is considerable room for additional research on these and other cases to better understand how "top-down" and "bottom-up" approaches perform and interact with one another to support integrated and adaptive water management. In particular, further research could help clarify how 
centralized authority can be exercised in a way that promotes broad and meaningful participation. In the EU, the future implementation of the WFD and the FD will provide an excellent context for this. In California, legislation was passed in 2014 that introduces, for the first time, statewide regulation of groundwater use, while still providing local water agencies with a considerable role and requiring extensive public participation [74]. This setting will provide an opportunity to assess how to balance "top-down" and "bottom-up" approaches to governing water resources.

Acknowledgments: We thank the Institute of International Studies of the University of California, Berkeley, for hosting and support the interdisciplinary faculty seminar in Water Management, whose members nurtured the ideas presented here and provided feedback on early versions of this paper. The staff of the Catalan Water Agency in Barcelona provided valuable information and insights. Three anonymous reviewers and the journal editor provided comments, which were extremely helpful in improving the paper.

Author Contributions: Anna Serra-Llobet wrote most of the paper and was responsible for the analysis of the Catalan coastal region. Esther Conrad conducted the analysis of the California IRWM process as a whole and most of the SF Bay Plan, and contributed knowledge of the water governance literature. Kathleen Schaefer contributed detailed knowledge of the flood risk management process in California and contributed to the analysis of the SF Bay Plan. All these authors actively discussed the issues and identified commonalities and differences between the two case study regions.

Conflicts of Interest: The authors declare no conflict of interest.

\section{Abbreviations}

The following abbreviations are used in this manuscript:

$\begin{array}{ll}\text { DWR } & \text { California Department of Water Resources } \\ \text { EU } & \text { European Union } \\ \text { FD } & \text { the EU Floods Directive } \\ \text { FEMA } & \text { the US Federal Emergency Management Agency } \\ \text { IRWM } & \text { Integrated Regional Water Management (the California program) } \\ \text { IWRM } & \text { Integrated Water Resource Management (the general approach/concept) } \\ \text { NFIP } & \text { National Flood Insurance Program } \\ \text { SF } & \text { San Francisco } \\ \text { US } & \text { United States } \\ \text { WFD } & \text { the EU Water Framework Directive }\end{array}$

\section{References}

1. Biswas, A.K. Integrated Water Resources Management: A reassessment: A water forum contribution. Water Int. 2004, 29, 248-256. [CrossRef]

2. Lenton, R.; Muller, M. Integrated Water Resources Management in Practice: Better Water Management for Development; Sterling, V.A., Ed.; Global Water Partnership/Earthscan: London, UK, 2009.

3. Global Water Partnership (GWP). What Is IWRM? Available online: http://www.gwp.org/en/TheChallenge/What-is-IWRM/ (accessed on 16 June 2016).

4. Molle, F. River-basin planning and management: The social life of a concept. Geoforum 2009, 40, 484-494. [CrossRef]

5. Folke, C.; Hahn, T.; Olsson, P.; Norberg, J. Adaptive governance of social-ecological systems. Annu. Rev. Environ. Resour. 2005, 30, 441-473. [CrossRef]

6. Kondolf, G.M.; Podolak, K.; Grantham, T.E. Restoring mediterranean-climate rivers. Hydrobiologia 2013, 719, 527-545. [CrossRef]

7. Intergovernmental Panel on Climate Change (IPCC). Summary for policymakers. In Climate Change 2014: Impacts, Adaptation, and Vulnerability. Part A: Global and Sectoral Aspects. Contribution of Working Group II to the Fifth Assessment Report of the Intergovernmental Panel on Climate Change; Cambridge University Press: Cambridge, UK; New York, NY, USA, 2014; p. 32.

8. Pahl-Wostl, C. Transitions towards adaptive management of water facing climate and global change. In Integrated Assessment of Water Resources and Global Change; Craswell, E., Bonnell, M., Bossio, D., Demuth, S., Van De Giesen, N., Eds.; Springer: Dordrecht, The Netherlands, 2006; pp. 49-62. 
9. Huntjens, P.; Pahl-Wostl, C.; Rihoux, B.; Schlüter, M.; Flachner, Z.; Neto, S.; Koskova, R.; Dickens, C.; Nabide Kiti, I. Adaptive Water Management and Policy Learning in a Changing Climate: A Formal Comparative Analysis of Eight Water Management Regimes in Europe, Africa and Asia: Adaptive Water Management and Policy Learning in a Changing Climate. Environ. Policy Gov. 2011, 21, 145-163. [CrossRef]

10. Benson, D.; Gain, A.K.; Rouillard, J.J. Water governance in a comparative perspective: From IWRM to a "nexus" approach? Water Altern. 2015, 8, 756-773.

11. American Water Resources Association (AWRA). Case Studies in Integrated Water Resources Management: From Local Stewardship to National Vision; AWRA Policy Committee. 2012. Available online: http://www.awra. org/committees / AWRA-Case-Studies-IWRM.pdf (accessed on 22 September 2016).

12. Medema, W.; McIntosh, B.S.; Jeffrey, P.J. From premise to practice: A critical assessment of Integrated Water Resources Management and adaptive management approaches in the water sector. Ecol. Soc. 2008, 13, 29.

13. Huitema, D.; Mostert, E.; Egas, W.; Moellenkamp, S.; Pahl-Wostl, C.; Yalcin, R. Adaptive water governance: Assessing the institutional prescriptions of adaptive (co-)management from a governance perspective and defining a research agenda. Ecol. Soc. 2009, 14, 16.

14. Huntjens, P.; Lebel, L.; Pahl-Wostl, C.; Camkin, J.; Schulze, R.; Kranz, N. Institutional design propositions for the governance of adaptation to climate change in the water sector. Glob. Environ. Chang. 2012, 22, 67-81. [CrossRef]

15. Pahl-Wostl, C. A conceptual framework for analysing adaptive capacity and multi-level learning processes in resource governance regimes. Glob. Environ. Chang. 2009, 19, 354-365. [CrossRef]

16. Newig, J.; Fritsch, O. Environmental governance: Participatory, multi-level—And effective? Environ. Policy Gov. 2009, 19, 197-214. [CrossRef]

17. Rouillard, J.J.; Benson, D.; Gain, A.K. Evaluating IWRM implementation success: Are water policies in Bangladesh enhancing adaptive capacity to climate change impacts? Int. J. Water Resour. Dev. 2014, 30, 515-527. [CrossRef]

18. Moss, T. Spatial fit, from panacea to practice: Implementing the EU Water Framework Directive. Ecol. Soc. 2012, 17, 2. [CrossRef]

19. Galaz, V.; Olsson, P.; Hahn, T.; Folke, C.; Svedin, U. The Problem of Fit among Biophysical Systems, Environmental and Resource Regimes, and Broader Governance Systems: Insights and Emerging Challenges. In Institutions and Environmental Change; Young, O.R., King, L.A., Schroeder, H., Eds.; The MIT Press: Cambridge, MA, USA, 2008; pp. 147-186.

20. Huntjens, P.; Pahl-Wostl, C.; Grin, J. Climate change adaptation in European river basins. Reg. Environ. Chang. 2010, 10, 263-284. [CrossRef]

21. World Meteorological Organization and the Global Water Partnership (WMO-GWP). Integrated Flood Management: Associated Programme on Flood Management, 2nd ed.; Technical Document No. 1. Available online: http:/ /www.gwp.org/Global/GWP-SAm_Files/Publicaciones/Gestión\%20de\%20Inundaciones / Integrated-Food-Management-2004.pdf (accessed on 22 September 2016).

22. Schanze, J. Flood risk management: A basic framework. In Flood Risk Management: Hazards, Vulnerability and Mitigation Measures; Schanze, J., Zeman, E., Marsalek, J., Eds.; Springer: Dordrecht, The Netherlands, 2006; Volume 67, pp. 1-20.

23. Hewitt, K. Regions of Risk: A Geographical Introduction to Disasters; Longman: Harlow, UK, 1997.

24. Sauri, D. Tendencias recientes en el análisis geográfico de los riesgos ambientales. Areas Rev. Cienc. Soc. 2003, 23, 17-30.

25. Schmid, M. The Role of Science in the Management of Natural Hazards and Major Risks: Scientific Expertise in Switzerland and within International Geneva; National Platform for Natural Hazards (PLANAT) c/o Hazard Prevention Division Federal Office of the Environment (FOEN): Bern, Switzerland, 2006; p. 50.

26. Ten Brinke, W.B.M.; Saeijs, G.E.M.; Helsloot, I.; van Alphen, J. Safety chain approach in flood risk management. Munic. Eng. 2008, 161, 93-102. [CrossRef]

27. Fokkens, B. The Dutch strategy for safety and river flood prevention. In Extreme Hydrological Events: New Concepts for Security; Vasiliev, O.F., van Gelder, P.H., Plate, E.J., Bolgov, M.V., Eds.; Springer: Dordrecht, The Netherlands, 2007; Volume 78, pp. 337-352.

28. White, G.F. Human Adjustments to Floods: A Geographical Approach to the Flood Problem in the United States; University of Chicago: Chicago, IL, USA, 1945. 
29. Conrad, E. Bridging the Hierarchical and Collaborative Divide: Learning in California's Integrated Regional Water Management Process; University of California: Berkeley, CA, USA, 2015.

30. Llasat, M.C.; Llasat-Botija, M.; Rodriguez, A.; Lindbergh, S. Flash floods in Catalonia: A recurrent situation. Adv. Geosci. 2010, 26, 105-111. [CrossRef]

31. European Environment Agency (EEA). Sustainable Water Use in Europe. Part 3: Extreme Hydrological Events: Floods and Droughts; Technical Report No 21/2001; EEA: Copenhagen, Denmark, 2001.

32. Intergovernmental Panel on Climate Change (IPCC). Climate Change 2014: Impacts, Adaptation, and Vulnerability. Part B: Regional Aspects. Contribution of Working Group II to the Fifth Assessment Report of the Intergovernmental Panel on Climate Change; Barros, V.R., Field, C.B., Dokken, D.J., Mastrandrea, M.D., Mach, K.J., Bilir, T.E., Chatterjee, M., Ebi, K.L., Estrada, Y.O., Genova, R.C., et al., Eds.; Cambridge University Press: Cambridge, UK; New York, NY, USA, 2014; pp. 1439-1498.

33. Llasat, M.C.; Barriendos, M.; Barrera, A.; Rigo, T. Floods in Catalonia (NE Spain) since the 14th century. Climatological and meteorological aspects from historical documentary sources and old instrumental records. J. Hydrol. 2005, 313, 32-47. [CrossRef]

34. Intergovernmental Panel on Climate Change (IPCC). Managing the Risks of Extreme Events and Disasters to Advance Climate Change Adaptation: A Special Report of Working Groups I and II of the Intergovernmental Panel on Climate Change; Field, C.B., Barros, V., Stocker, T.F., Qin, D., Dokken, D.J., Ebi, K.L., Mastrandrea, M.D., Mach, K.J., Plattner, G.K., Allen, S.K., et al., Eds.; Cambridge University Press: Cambridge, UK; New York, NY, USA, 2012.

35. Direcció General de Protecció Civil. INUNCAT. Pla Especial d'emergències per Inundacions de Catalunya; Direcció General de Protecció Civil-Generalitat de Catalunya: Barcelona, Spain, 2014.

36. Heberger, M.; Cooley, H.; Herrera, P.; Gleick, P.H.; Moore, E. Potential impacts of increased coastal flooding in California due to sea-level rise. Clim. Chang. 2011, 109, 229-249. [CrossRef]

37. Department of Water Resources (DWR). California's Flood Future—Highlights; DWR: Cambridge, MA, USA, 2013. Available online: http://www.water.ca.gov/waterplan/docs/cwpu2013/Final/00-CWP-Update2013_ Highlights_FINAL_10-28-2014.pdf (accessed on 22 September 2016).

38. Diari Oficial de la Generalitat de Catalunya (DOGC). Legislative Decree 3/2003, of 4 November Decret Legislatiu 3/2003, de 4 de Novembre, pel qual s'aprova el Text Refós de la Legislació en Matèria d'aigües de Catalunya; Generalitat de Catalunya: Barcelona, Spain, 2003.

39. Agència Catalana de l'Aigua (ACA). Proposta de Pla de Gestió del Risc D'inundació del Districte de Conca Fluvial de Catalunya (2016-2021); Department de Territori i Sostenibilitat—Departament d'Interior, Generalitat de Catalunya: Barcelona, Spain, 2015; p. 119.

40. Agència Catalana de l'Aigua (ACA). Pla de Gestió del Discticte Conca Fluvial de Catalunya (2009-2015); Departament de Medi Ambient i Habitatge, Generalitat de Catalunya: Barcelona, Spain, 2009; p. 403.

41. Martí-Llambrich, C. La Transformació del Paisatge Litoral de la Costa Brava: Anàlisi de l'evolució (1956-2003): Diagnosi de L'estat Actual i Prognosi de Futur; Universitat de Girona: Girona, Spain, 2005.

42. Olcina, J.; Sauri, D.; Hernández, M.; Ribas, A. Flood policy in Spain: A review for the period 1983-Disaster. Prev. Manag. Int. J. 2016, 25, 41-58.

43. Pérez-Morales, A.; Gil-Guirado, S.; Olcina-Cantos, J. Housing bubbles and the increase of flood exposure. Failures in flood risk management on the Spanish south-eastern coast (1975-2013): Housing bubbles and increase of flood risk in Spain. J. Flood Risk Manag. 2015. [CrossRef]

44. San Francisco Bay Area IRWM Region Coordinating Committee. San Francisco Bay Area Integrated Regional Water Management Plan. 2013. Available online: http://bairwmp.org/docs/2013-bairwm-planupdate/2013-final-plan/San\%20Francisco\%20Bay\%20Area\%20IRWMP\%20Final_September\%202013.pdf/ at_download/file (accessed on 22 September 2016).

45. Barraqué, B. The common property issue in flood control through land use in France: The Common property issue in French flood control. J. Flood Risk Manag. 2014. [CrossRef]

46. Menéndez Prieto, M. Chapter facing the challenges of implementing the European Water Directive in Spain. In Water Policy in Spain; Garrido, A., Llamas, M.R., Eds.; CRC Press/Taylor \& Francis Group: Boca Raton, FL, USA, 2009.

47. Serra-Llobet, A.; Tàbara, J.D.; Sauri, D. The Tous dam disaster of 1982 and the origins of integrated flood risk management in Spain. Nat. Hazards 2013, 65, 1981-1998. [CrossRef] 
48. Kaika, M. The Water Framework Directive: A new Directive for a changing social, political and economic European framework. Eur. Plan. Stud. 2003, 13, 299-316. [CrossRef]

49. European Union (EU). Directive 2000/60/EC of the European Parliament and of the Council of 23 October 2000 Establishing a Framework for Community Action in the Field of Water Policy. 2000. Available online: http:/ /ec.europa.eu/health/endocrine_disruptors/docs/wfd_200060ec_directive_en.pdf (accessed on 22 September 2016).

50. DG Environment towards Better Environmental Options in Flood Risk Management. Available online: http:/ /ec.europa.eu/environment/water/flood_risk/better_options.htm (accessed on 16 June 2016).

51. González del Tánago, M.; García de Jalón, D.; Román, M. River Restoration in Spain: Theoretical and Practical Approach in the Context of the European Water Framework Directive. Environ. Manag. 2012, 50, 123-139. [CrossRef] [PubMed]

52. European Union (EU). Directive 2007/60/EC of the European Parliament and of the Council of 23 October 2007 on the Assessment and Management of Flood Risks. 2007. Available online: http:/ / eur-lex.europa.eu/legalcontent/EN/TXT/PDF/?uri=CELEX:32007L0060\&from=EN (accessed on 22 September 2016).

53. Huffman, J.L. The federal role in water resource management. NYU Environ. Law J. 2008, 17, $2009-2018$.

54. Dworsky, L.B.; Allee, D.J.; North, R.M. Water resources planning and management in the United States federal system: Long term assessment and intergovernmental issues. Nat. Resour. J. 1991, 34, 475-547.

55. Lopez-Llompart, P.; Kondolf, G.M. Encroachments in floodways of the Mississippi River and Tributaries Project. Nat. Hazards 2016, 81, 513-542. [CrossRef]

56. Shabman, L.; Scodari, P. Towards Integrated Water Resources Management: A Conceptual Framework for U.S. Army Corps of Engineers Water and Related Land Resources Implementation Studies; Report 2012-VSP-01; U.S. Army Corps Institute for Water Resources. 2012. Available online: http://www.iwr.usace.army.mil/Portals/70/ docs/iwrreports/2012-VSP-01.pdf (accessed on 22 September 2016).

57. Hundley, N., Jr. The Great Thirst: Californians and Water-A History; University of California Press: Berkeley, CA, USA, 2001.

58. Department of Water Resources (DWR). California Water Plan Update 2013 (Bulletin 160-03); California Natural Resources Agency: Sacramento, CA, USA, 2014.

59. Department of Water Resources (DWR). IRWM Grant Program Legislation. Available online: http://www. water.ca.gov/irwm/grants/legislation.cfm (accessed on 16 May 2016).

60. Water Education Foundation (WEF). Layperson's Guide to Integrated Regional Water Management; WEF: Sacramento, CA, USA, 2013.

61. California Department of Water Resources (DWR). Central Valley Flood Protection Plan. 2012. Available online: http://www.water.ca.gov/cvfmp/docs/2012_CVFPP_FullDocumentHighRes_20111230.pdf (accessed on 22 September 2016).

62. Conrad, E. Regional Governance of Flood Management in the Central Valley: An Analysis of the Integrated Regional Water Management and Regional Flood Management Planning Processes. 2014. Available online: http://www.water.ca.gov/climatechange/docs/IRWM_RFMP_FinalReport_May2014.pdf (accessed on 22 September 2016).

63. Paul, R.; Bouder, F.; Wesseling, M. Risk-based governance against national obstacles? Comparative dynamics of Europeanization in Dutch, French, and German flooding policies. J. Risk Res. 2015, 19, 1-20. [CrossRef]

64. Porter, J.; Demeritt, D. Flood-risk management, mapping, and planning: The institutional politics of decision support in England. Environ. Plan. A 2012, 44, 2359-2378. [CrossRef]

65. Department of Water Resources (DWR). Proposition 84 and Proposition 1E Integrated Regional Water Management Guidelines. 2012. Available online: http:/ /www.water.ca.gov/irwm/grants/docs/Archives/ Prop84/Guidelines_PSPs/GL_2012_FINAL.pdf (accessed on 22 September 2016).

66. Jager, N.; Challies, E.; Kochskämper, E.; Newig, J.; Benson, D.; Blackstock, K.; Collins, K.; Ernst, A.; Evers, M.; Feichtinger, J.; et al. Transforming European Water Governance? Participation and River Basin Management under the EU Water Framework Directive in 13 Member States. Water 2016, 8, 156. [CrossRef]

67. Mukheibir, P.; Kuruppu, N.; Gero, A.; Herriman, J. Overcoming cross-scale challenges to climate change adaptation for local government: A focus on Australia. Clim. Chang. 2013, 121, 271-283. [CrossRef]

68. Lubell, M.; Lippert, L. Integrated regional water management: A study of collaboration or water politics-as-usual in California, USA. Int. Rev. Adm. Sci. 2011, 77, 76-100. [CrossRef] 
69. Agència Catalana de l'Aigua (ACA). Pla de Gestió del Discticte Conca Fluvial de Catalunya i Programa de Mesures (2016-2021); Document Síntesi; Departament de Territori i Sostenibilitat, Generalitat de Catalunya: Barcelona, Spain, 2015; p. 42.

70. Technical Mapping Advisory Council (TMAC). TMAC Future Conditions Risk Assessment and Modeling; Federal Emergency Management Agency, 2015. Available online: http:/ /www.water.ca.gov/cvfmp/docs / 2012_CVFPP_FullDocumentHighRes_20111230.pdf (accessed on 22 September 2016).

71. Hahn, T.; Olsson, P.; Folke, C.; Johansson, K. Trust-building, Knowledge Generation and Organizational Innovations: The Role of a Bridging Organization for Adaptive Comanagement of a Wetland Landscape around Kristianstad, Sweden. Hum. Ecol. 2006, 34, 573-592. [CrossRef]

72. Crona, B.I.; Parker, J.N. Learning in support of governance: Theories, methods, and a framework to assess how bridging organizations contribute to adaptive resource governance. Ecol. Soc. 2012, 17, 32. [CrossRef]

73. Mahoney, J.; Thelen, K.A. (Eds.) Explaining Institutional Change: Ambiguity, Agency, and Power; Cambridge University Press: Cambridge, UK; New York, NY, USA, 2010.

74. Leahy, T.C. Desperate times call for sensible measures: The making of the California Sustainable Groundwater Management Act. Gold. Gate Envtl. J. 2015, 9, 5-40.

(C) 2016 by the authors; licensee MDPI, Basel, Switzerland. This article is an open access article distributed under the terms and conditions of the Creative Commons Attribution (CC-BY) license (http://creativecommons.org/licenses/by/4.0/). 